\title{
OXYGEN UPTAKE IN GREEN IGUANA (IGUANA IGUANA) INJECTED WITH BACTERIA*
}

\author{
Mark D. Malvin and Matthew J. Kluger \\ Department of Physiology, University of Michigan Medical School, Ann Arbor. Michigan 48109, U.S.A.
}

(Received 10 July 1978; accepted 3 Septemher 1978)

\begin{abstract}
Green iguanas (I. iguana) were maintained at a constant body temperature of $35.5 \mathrm{C}$ and injected with either saline or a dose of bacteria which had been previously shown to induce a fever by $3 \mathrm{~h}$ post-injection.

2. There were no significant differences in the oxygen uptake between the lizards injected with saline and bacteria.

3. We conclude that green iguanas do not increase their internal heat production as an effector response to the raised thermoregulatory "set-point" that occurs during fever.
\end{abstract}

\section{INTRODUCTION}

FEVERS in response to injections of bacteria are known to occur in mammals, birds, reptiles, amphibians and fishes (see for example, Reynolds \& Covert, 1977; and Kluger, 1978). In the endothermic vertebrates (mammals and birds) the elevation of body temperature is largely by physiological means (e.g., increased heat production). On the other hand in the ectothermic vertebrates (reptiles, amphibians and fish) the elevation in body temperature is largely, if not entirely, by behaviour. For example, the febrile reptile selects a higher environmental temperature and as a result its body temperature increases (Bernheim \& Kluger, 1976).

It has recently been shown that green iguanas (Iguana iguana) develop a fever in response to injection of dead or live pathogenic bacteria (Aeromonas hydrophila) (Kluger, 19.78). In that study a dose of bacteria of $0.2 \mathrm{ml}$ of $2 \times 10^{10}$ dead bacteria/ml was injected and this led to a fever within $3 \mathrm{~h}$ of the injection. By $5 \mathrm{~h}$ post-injection, body temperature had risen by approximately $5^{\circ} \mathrm{C}$.

Although the rise in body temperature in ectotherms in response to pyrogens has been shown to be caused by behavioural changes (e.g. selecting a warmer microhabitat) it is possible that there are also physiological components to the febrile response. For example, it is possible that in an ectotherm, such as the green iguana, their metabolic heat production might rise simultaneously with the development of the elevated "set-point" or fever. This rise in metabolic heat production might precede the elevation in body temperature and, in fact, might occur even if the lizards were prevented from raising their body temperature.

In order to test this hypothesis green iguanas were maintained at a constant body temperature and their oxygen uptake was measured before and after injection of either bacteria or sterile pyrogen-free saline.

\section{MATERIALS AND METHODS}

Five green iguanas (Iguana iguana) ranging in weight from 316 to $1088 \mathrm{~g}$ were maintained in a large

\footnotetext{
* Research Supported by NIH AI 13878.
}

bin $(1 \mathrm{~m} \mathrm{dia})$ on a $12 \mathrm{~h}$ light/dark photoperiod. A $250 \mathrm{~W}$ heat lamp was suspended over one side of the cage to permit the lizards to select a "preferred" environmental temperature ranging from room temperature $\left(\mathrm{ca} .22^{\circ} \mathrm{C}\right)$ to over $40^{\circ} \mathrm{C}$. The lizards were fed ad libitum a diet of leaf lettuce, water and mealworms.

Approximately $15 \mathrm{~h}$ prior to the beginning of each experimental run, the test animal was isolated from the bin. A copper-constantan thermocouple covered with polyethylene tubing (P.E. 160) was inserted into the animal's cloaca and the lizard was then placed in an air-tight container which was placed inside of a Sherer temperature chamber. This procedure allowed an acclimation period for each lizard prior to the experiment. The experiments were always performed between $0900-1700 \mathrm{~h}$ to avoid circadian variation.

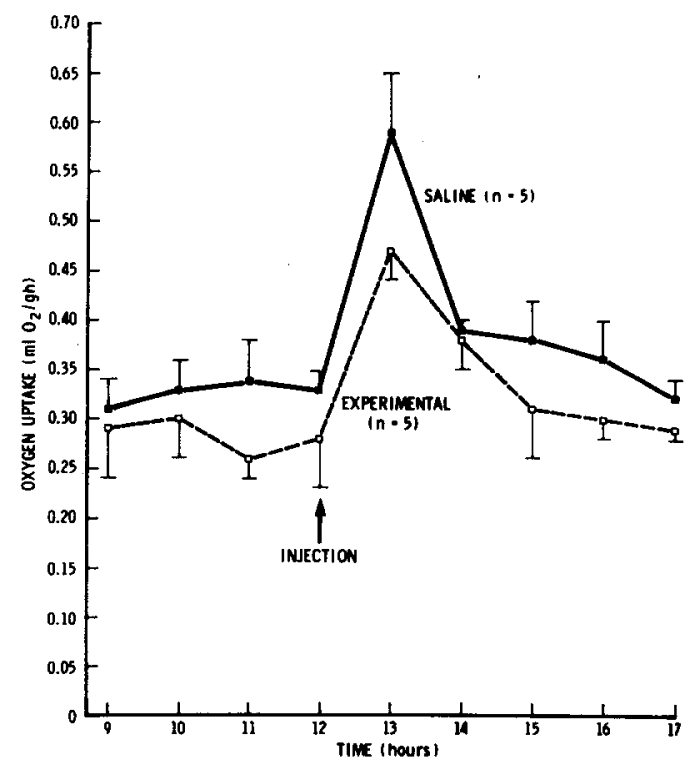

Fig. 1. Oxygen uptake vs time for green iguanas (I. iguana) maintained at a constant body temperature of $35.5^{\circ} \mathrm{C}$ and injected at $1200 \mathrm{~h}$ with either saline or dead bacteria (experimental). 
Oxygen uptake was measured using a Beckman OM-14 oxygen analyzer. A constant air flow of 1000 $\mathrm{ml} / \mathrm{min}$ (corrected for STP) was dried (Drierite), drawn into the animal container, dried again (Drierite) and then sampled by the oxygen analyzer. The oxygen uptake of each lizard (as $\mathrm{ml} \mathrm{O}_{2} / \mathrm{g}$.h) was determined hourly. Body temperature, container temperature and chamber temperature were monitored continuously using a Honeywell 112 multipoint temperature recorder. Lizard body temperature (equivalent to container temperature) was maintained at $35.5 \mathrm{C} \pm 0.2 \mathrm{C}$, the mean body temperature of uninfected green iguanas (Kluger, 1978).

After four hours of continuous oxygen uptake sampling, each lizard was injected with either $0.2 \mathrm{ml}$ of $2 \times 10^{10} / \mathrm{cm}^{3}$ heat-killed Aeromonas hydrophila in $0.9 \%$ pyrogen-free saline or $0.2 \mathrm{ml}$ of $0.9 \%$ pyrogen-free saline. The preparation of the bacteria has been described earlier (Bernheim \& Kluger 1976). Oxygen uptake was again determined hourly. Each lizard was used four times, twice being injected with bacteria and with saline.

Data were analyzed using paired $t$-tests.

\section{RESULTS}

The mean oxygen uptake during the control period was $0.33 \pm 0.02$ S.E. $\mathrm{ml} \mathrm{O}_{2} / \mathrm{g} . \mathrm{h}$ in the controls $(n=5)$ and $0.28 \pm 0.04$ S.E. in the experimental $(n=5)$ $(P<0.4)$ (Fig. 1). Following the injection of either saline or bacteria (at $1200 \mathrm{~h}$ ) oxygen uptake increased $79 \%$ in the controls and $68 \%$ in the bacteriallyinfected lizards within the first hour. These initial increases were most likely due to the handling of the lizard during injections and to the "stress" associated with intracardiac injections.

Since in an earlier study (Kluger. 1978) it was shown that following the injection of bacteria the lizard began to develop a fever by the third hour post-injection, the critical period for this experiment were hours $1500-1700$. The mean oxygen uptake during this period for the controls was $0.35 \pm 0.02 \mathrm{~S}$.E. $\mathrm{ml} \mathrm{O}_{2} / \mathrm{g} . \mathrm{h}$ and for the experimentals was $0.31 \pm 0.01$ S.E. $\mathrm{ml} \mathrm{O}_{2} / \mathrm{g} . \mathrm{h}(P<0.3)$. The net increases in oxygen uptake between the control period $(0900-1200 \mathrm{~h})$ and the experimental period $(1500-1700 \mathrm{~h})$ were $0.02 \mathrm{ml}$ $\mathrm{O}_{2} / \mathrm{g} . \mathrm{h}$ for the lizards injected with saline and $0.03 \mathrm{ml}$ $\mathrm{O}_{2} / \mathrm{g}$.h for the lizards injected with dead bacteria. These small increases were not statistically significant $(P<0.4)$.

\section{DISCUSSION}

These data indicate that injection of lizards with pathogenic bacteria does not result in a rise in oxygen uptake (when body temperature is maintained at afebrile levels). We conclude, therefore, that green iguanas do not increase their internal heat production in response to the raised thermoregulatory "set-point" that occurs during fever.

\section{REFERENCES}

Bernheim H. A. \& Kluger M. J. (1976) Fever and antipyresis in the lizard Dipsosaurus dorsalis. Am. J. Physiol. 231, 833-842.

KLUGer M. J. (1978) The evolution and adaptive value of fever. Am. Scient. 66, 38-43.

ReYnolds W. W. \& Covert J. B. (1977) Behavioral fever in aquatic ectothermic vertebrates. In Drugs, Biogenic Amines and Body Temperature (Edited by COOPER $\mathbf{K}$. E., Lomax P. \& Schonbaum E.), pp. 108-110. Karger, Basel.

Key Word Index-Temperature: Iguana iguana; Aeromonas hydrophila; fever; lizards; oxygen uptake. 